\title{
Potential application of triticale cultivar "Odisej" for the production of cookies
}

\author{
Miona Belović ${ }^{*}$. Aleksandra Torbica ${ }^{1}$ Dubravka Škrobot ${ }^{1}$. Jelena Tomić - Ivana Čabarkapa ${ }^{1}$. \\ Dragan Živančev ${ }^{2}$ Slaviša Štatkić́ · Vladimir Aćin ${ }^{2} \cdot$ Kristína Kukurováa $^{3} \cdot$ Zuzana Ciesarováa $^{3}$
}

\author{
${ }^{1}$ University of Novi Sad, Institute of Food Technology in Novi Sad, Serbia \\ Institute of Field and Vegetable Crops, Novi Sad, Serbia \\ ${ }^{3}$ NPPC VÚP National Agricultural and Food Centre in Slovakia, Food Research Institute, Slovakia
}

\begin{abstract}
Summary: Triticale, a hybrid cereal developed by crossing of wheat and rye, has certain advantages over wheat, such as higher environmental tolerance and higher content of dietary fibers. The application of triticale flour in food industry is limited by poor rheological properties of dough and low gluten strength. Potential application of the hexaploid triticale cultivar "Odisej" for the production of cookies was assessed in this study. Additionally, the values of basic grain quality parameters for "Odisej" were determined, such as hectoliter weight, thousand kernel weight, grain size, protein and wet gluten content, gluten index and falling number. Cookies were prepared from refined and wholegrain triticale flour and their physical properties (dimensions, color, and hardness) and sensory properties were compared to the cookies prepared from refined and wholegrain wheat and rye flour. Cookies manufactured from the refined triticale flour had high spread ratio (diameter/high) value, similar to that of cookies prepared from refined wheat flour. Total sensory score of the cookies manufactured from refined triticale flour was the highest among all samples, indicating that it can successfully be used in cookies production. The quality of wholegrain triticale cookies could be improved by the use of milling technique adequate for the production of wholegrain flour.

Key words: cookies, cultivars, grains, triticales, wheats
\end{abstract}

\section{Introduction}

Triticale (x Triticosecale Wittmack) is a hybrid cereal developed by crossing wheat (Triticum sp.) and rye (Secale cereale $\mathrm{L})$. It combines the grain quality of wheat with the disease and environmental tolerance of rye (Zhu, 2018). Wheat is used as a female parent, and rye is used as a male parent, but commercially available triticale is usually a second-generation hybrid (Stallknecht et al., 1996). Triticale hybrids include: tetraploid (Triticum monococcum $\times$ Secale cereale, genome AARR), hexaploid (genome AABBRR) and octaploid

\section{Corresponding author:}

miona.belovic@fins.uns.ac.rs

Acknowledgments:

This study results from the grant no, 337-00-107/2019-09/02 titled "Collaborative study of acrylamide occurrence and qualitative aspects of Triticale-based confectionery products" funded by Slovak Research and Development Agency, and TR31007 "Vrednovanje kvaliteta i optimizacija prerade pšenice u svetlu klimatskih promena" funded by the Ministry of Education, Science and Technological Development of the Republic of Serbia.

Cite this article:

Belović M., Torbica A., Škrobot D., Tomić J., Čabarkapa I., Živančev D. Štatkić S., Aćin V., Kukurová K. (2020). Potential application of triticale cultivar "Odisej" for the production of cookies. Ratar. Pourt., 57 (1), 8-13. triticale (Secale cereale $\times$ Triticum aestivum, genome AABBDDRR) cultivars (Hammer et al., 2011), depending on the parents. The expression of rye genes is especially hard to see in the background of wheat cytoplasm due to the predominant wheat nuclear genome. Therefore, the potential of rye in disease resistance and ecological adaptation is hard to understand.

Triticale "Odisej" is a Serbian hexaploid cultivar registered in 2003 and after the expiration it was reregistered in 2016 in order to remain in the current assortment (http://www.sorte.minpolj.gov.rs/sites/ default/files/rsprilogom_3.pdf). Odisej is a very early maturing cultivar, with excellent winter hardness and average stem height ranging from 100 to $110 \mathrm{~cm}$. Moreover, it possesses very good resistance to prevalent diseases and excellent resistance to lodging (Banjac et al., 2014, Maširević et al. 2013). Triticale is characterized with higher yields than wheat, especially on low quality soils and in harsh climate conditions. Some triticale genotypes possess a high concentration of lysine, essential amino acid in which cereals are usually deficient (Wu et al., 1978). It is the most commonly used as a feed for pigs, poultry and ruminants. In the recent decades, triticale has increasingly been used for 
bioethanol production (McGoverin et al., 2011). Its application in food and beverage industry is still limited despite the researches which showed its suitability for the production of food (bread, cookies, pasta) and beverages (beer, spirit) (Zhu, 2018). One of the reasons for limited application of triticale in the bakery industry is its low milling efficiency comparing to common wheat (Dennett \& Trethowan, 2013). Other reasons are low viscosity and stickiness of dough, poor rheological properties and low gluten strength. Despite these disadvantages, several studies have shown that triticale flour can be suitable for the manufacture of products that does not require flour with strong gluten, such as breakfast cereals, different cakes, cookies and crackers (Wu et al., 1978; Leon et al., 1996; Pérez et al., 2003). In the study of Oliete et al. (2010), cakes prepared from triticale flour had textural properties similar to cakes prepared from wheat flour, but their color properties were significantly different from wheat cakes. However, not all triticale cultivars are suitable for application in cakes and cookies; cultivars with low protein content, high ratio of prolamins to glutelins and low content of free sulfhydryl groups were shown to give the highest quality of cookies (Leon et al., 1996).

Cookies are popular sweet baked products, consisting of three major ingredients - flour, sugar and fat. Cookie dough is characterized with low water content and its rheological properties are mainly influenced by these three components of dough. Therefore, gluten network in cookie dough is developed in lesser extent than in bread dough (Torbica et al., 2012; Hadnađev et al., 2013). Although there are different types of cookies and they have different names in different countries (e.g. biscuits), their quality is characterized with spread ratio, appearance, texture and flavor (AACC, 2000a; Torbica et al., 2012).

The main aim of this study was to evaluate the quality of cookies prepared from flour of triticale cultivar Odisej in comparison with cookies prepared from wheat and rye flours. The values of grain quality parameters for cultivar Odisej which are important for food industry were also defined in this study.

\section{Material and Methods}

Triticale (x Triticosecale, cv. Odisej) was grown in an experimental field of the Institute of Field and Vegetable Crops in Novi Sad at site Rimski Šančevi, Novi Sad, Serbia ( $45^{\circ} 20^{\prime} \mathrm{N}, 19^{\circ} 51^{\prime} \mathrm{E}$ ). Conventional cultural practices were applied in the test plot. The size of the experimental stripe was $125 \mathrm{~m}^{2}(2.5 \times 50 \mathrm{~m})$. Planting was on optimum dates (from 10 to 25 October) in the trial year. The seeding rate of 500 viable seed $\mathrm{sm}^{-2}$ was used since it was shown to give optimal yields in practice (Malešević et al., 2010). Odisej was grown in only one stripe without field replication.

The moisture of triticale grain was measured using
NIR analyzer Infratec 1241 (Foss, Denmark) with chosen triticale calibration TR002126. Water was added to grain in order to adjust the moisture to $16 \pm 0.5 \%$ before milling, according to CEN/TS 15731:2008 (E) (CEN, 2008). Automatic shaker (model MR2L, Chopin, France) was used to distribute the moisture uniformly. Triticale grain was milled using Quadrumat ${ }^{\circledR}$ Senior roller mill (Brabender, Germany), and the yield of refined flour was in the range of $66-68 \%$. Part of refined flour was combined with bran in ratio 70:30 to obtain wholegrain triticale flour. Refined and wholegrain flours obtained from common wheat and rye (purchased from Mlyn Kolárovo a.s., Slovakia) were used as a control for the comparison of technological quality. Other ingredients used for the production of cookies (crystal sugar, butter, salt, sodium hydrogen carbonate and ammonium hydrogen carbonate) were purchased at the market.

For cultivar Odisej, hectoliter weight, thousand kernel weight, protein content and wet gluten content were determined according to ISO method 7971-3 (ISO, 2019), ISO method 520 (ISO, 2010), AACC Method 46-10 (AACC, 2000b) and ICC Standard method 106/2 (ICC, 1984), respectively. Modified ICC Standard method 155 (ICC, 1994) was used to determine gluten index of triticale flour; namely, refined triticale flour was sieved through the sieve with opening of $118 \mu \mathrm{m}$ (Bühler, Switzerland) prior to analysis. Grain size was determined using Sortimat device (Falling number, Sweden), equipped with sieves with openings of 2.2, 2.5 and $2.8 \mathrm{~mm}$. The Falling number method (ISO 3093:2009(E)) was used to estimate the $\alpha$ amylolytic activity of flour using automatic Falling number device (Perten, Sweden).

Moisture of wheat, rye and triticale refined and wholegrain flours was determined according to ISO 712:2009, and the obtained values were used to determine the amount flour and water for needed for cookie test baking. Test baking of cookies was performed according to AACC Method 10-54.01 (AACC, 2000a), with slight modifications. Namely, the obtained dough was cut into round shape with cutter of $30 \mathrm{~mm}$ diameter to obtained larger number of cookies. Diameters (d) and heights (h) of six cookies were measured using digital caliper, and the spread ratio (SP) was calculated by dividing diameter $(\mathrm{mm})$ with height (mm) (AACC, 2000a).

TA.XTPlus Texture Analyser (Stable Micro Systems, Godalming, UK) was used to determine the hardness of cookies, defined as the maximum peak force recorded from force/time curve. Due to small dimensions of cookies, biscuit cutting method was chosen, and instrumental settings (project BIS2_KB) were taken from the sample projects of the software package (Texture Exponent Software TEE32, version 6.1.6.0., Stable Micro Systems, Godalming, UK) with some modifications (distance $=10 \mathrm{~mm}$ ). The instrument was equipped with a flat blade (HDP/BS), 
and a $30 \mathrm{~kg}$ load cell. The color of cookies was measured at top and bottom surface of ten cookies per samples using Chroma Meter CR-400 (Konica Minolta Co., Ltd., Osaka, Japan). The results were expressed in CIE $\mathrm{L}^{*} \mathrm{a}^{*} \mathrm{~b}^{*}$ color space, where CIE $\mathrm{L}^{*}$ represents lightness $\left(\mathrm{L}^{*}=0-\right.$ black, $\mathrm{L}^{*}=100-$ white), CIE a* represents red-green hues $\left(+\mathrm{a}^{*}=\right.$ redness, $-\mathrm{a}^{*}=$ greenness) and CIE $b^{*}$ represents yellow-blue hues $\left(+b^{*}\right.$ $=$ yellowness, $-\mathrm{b}^{*}=$ blueness). Values were read using a $\mathrm{D}_{65}$ light source and the observer angle of $2^{\circ}$.

Scoring method with coefficients of importance was used to determine the sensory quality of cookies (Pajin, 2009). Ten sensory panelists (8 women and 2 men, aged between 25 to 50 years) from the Institute of Food Technology, with extensive experience in the assessment of cookies, performed the sensory analysis in laboratory conformed to International Standard (ISO, 2010). Appearance (surface, shape), structure and fracturability, chewiness, odor, and taste and flavor were assessed using scores from 1 - unacceptable to 5 excellent. Each score was described with words, using previously prepared standard. Scores given to each attribute were multiplied with coefficients of importance (CI), which were defined according to their importance for the overall sensory quality of cookies. The CI were balanced that their sum equals to 5 , as follows: $\mathrm{IC}=0.8$ for appearance, structure and fracturability and chewiness; IC $=0.6$ for odor; IC $=$ taste and flavor. The obtained weighted scores were summed up to the total

Table 1. The values of grain quality parameters for triticale cultivar 'Odisej'

\begin{tabular}{|c|c|}
\hline Quality parameter & 'Odisej' \\
\hline Hectoliter weight $(\mathrm{kg} / \mathrm{hl})$ & $75-79$ \\
\hline Thousand kernel weight $(\mathrm{g})$ & $47-49$ \\
\hline Protein $(\%)$ & $12-14$ \\
\hline Wet gluten $(\%)$ & $21-26$ \\
\hline Gluten index* (\%) & $46 \pm 0.0$ \\
\hline Falling number* (s) & $130 \pm 1.4$ \\
\hline \multicolumn{2}{|l|}{ Grain size $(\%)$} \\
\hline$>2.8 \mathrm{~mm}$ & $26-29$ \\
\hline $2.5 \mathrm{~mm}<\mathrm{X}<2.8 \mathrm{~mm}$ & $45-48$ \\
\hline $2.2 \mathrm{~mm}<\mathrm{X}<2.5 \mathrm{~mm}$ & $11-12$ \\
\hline$<2.2 \mathrm{~mm}$ & $14-16$ \\
\hline
\end{tabular}

number of points, which is used to classify the product into appropriate quality category.

Software Statistica 13.3 (Tibco Inc., USA, 2017, https://www.tibco.com/products/data-science) was used to analyze the obtained data. One-way analysis of variance (ANOVA) and Fisher's least significant differences (LSD) test were used to determine the significant differences between the samples and classify them into homogenous groups $(\mathrm{p}<0.05)$.

\section{Results and Discussion}

The values of grain quality parameters obtained for triticale cultivar Odisej are presented in Table 1. Interval values were obtained from several production seasons and from multiple individual samples. Its hectoliter weight and protein content are in the range of values obtained for different common wheat (Triticum aestivum L.) cultivars. Values obtained for protein (12-14\%) and wet gluten content $(21-26 \%)$ indicate potential quality for the production of cookies (Gavrilović, 2000), and could be linked to the decreased intensity of secalin accumulation (Grabovets et al., 2013). Low gluten index value indicates that triticale flour possesses weak gluten, which is desirable property for its application in cookie industry. Odisej had higher ratio of longer grains $(>2.5$ $\mathrm{mm})$ and consequently higher thousand kernel weight than common wheat, which is the main morphological characteristic of grain of modern triticale cultivars (Dennett \& Trethowan, 2013). Its relatively low falling number value could be linked to the activity of late maturity $\alpha$-amylase (LMA) (Dennett et al., 2013). However, other factors, such as starch properties, could also cause low falling number values. It is also important to notice that no sprouted grains were observed in the analyzed sample. Samples from several production years with different growing conditions have to be collected before any final conclusion on the $\alpha$-amylolytic activity of cv. Odisej is drawn.

The yield of refined flour (66-68\%) obtained by milling of triticale cultivar Odisej was similar to that usually obtained for wheat on the same mill. However, it is important to point out that these results cannot, in absolute value, be directly compared to the results obtained at the other laboratory or industrial mill.

Refined and wholegrain wheat and rye flours were used for the preparation of control cookies, and the basic quality parameters of these flours are given in Table 2. Wet gluten and gluten index values could not

Table 2. Basic quality parameters of refined and wholegrain wheat and rye flours

\begin{tabular}{|c|c|c|c|c|}
\hline Sample & Protein $(\%)$ & Falling number (s) & Wet gluten $(\%)$ & Gluten index $(\%)$ \\
\hline Refined wheat flour & $11.59 \pm 0.02$ & $480 \pm 1.4$ & $28.6 \pm 0.1$ & $94 \pm 0.7$ \\
\hline Wholegrain wheat flour & $14.70 \pm 0.03$ & $397 \pm 4.2$ & $33.0 \pm 0.6$ & $90 \pm 1.4$ \\
\hline Refined rye flour & $9.01 \pm 0.01$ & $303 \pm 6.4$ & - & - \\
\hline Wholegrain rye flour & $10.33 \pm 0.05$ & $277 \pm 7.1$ & - & - \\
\hline
\end{tabular}

Results are expressed as means \pm standard deviations for three replications. 
be determined for rye flours due to the presence of pentosans, which obstructed gluten separation. Falling number values of rye flours are lower values of wheat flours. However, this difference can be attributed more to the differences in starch properties than to $\alpha$ amylolytic activity (Perten, 1964).

The quality of cookies prepared from refined and wholegrain wheat, rye and triticale flours was defined by physical (Table 3) and sensory (Table 4) properties. Photograph of prepared cookies is presented in Figure 1. Spread ratio is one of the most important physical properties, since large diameter (d) and low height (h) of cookies are desirable for automated industrial production (Hadnađev et al., 2013). It is interesting to notice that spread ratio (SR) values were grouped according to the type of flour (refined or wholegrain), without significant differences among the species. Generally, low spread ratio is linked to high waterholding capacity of flour (Roccia et al., 2006), explaining the observed difference by the presence of bran particles which can easily bind water. This is confirmed by the fact that wholegrain triticale flour had the lowest spread ratio and the highest amount of coarse bran particles.

Hardness is also an important quality parameter because it should be high enough to keep the cookie from breaking during transport and low enough to make the cookie break easily during consumption (Hadnađev et al., 2013). All hardness values obtained for rye and triticale cookies, except for those made from wholegrain triticale flour were inside the range encompassed by cookies made from wheat flour, indicating that these values are satisfactory for transport and consumption. Additionally, previous experiments revealed that wheat cookies containing optimal amount of fat and sugar have hardness values in the range of 2000 to 3000 g (Hadnađev et al., 2013), which corresponds well with our results. High hardness of wholegrain triticale flour cookies originates from coarse bran particles.

Table 3. Physical properties of cookies

\begin{tabular}{|c|c|c|c|c|c|c|c|}
\hline \multicolumn{2}{|c|}{ Quality parameter } & $\begin{array}{c}\text { Refined wheat } \\
\text { flour }\end{array}$ & $\begin{array}{l}\text { Wholegrain } \\
\text { wheat flour }\end{array}$ & $\begin{array}{l}\text { Refined rye } \\
\text { flour }\end{array}$ & $\begin{array}{l}\text { Wholegrain } \\
\text { rye flour }\end{array}$ & $\begin{array}{c}\text { Refined } \\
\text { triticale flour }\end{array}$ & $\begin{array}{l}\text { Wholegrain } \\
\text { triticale flour }\end{array}$ \\
\hline \multicolumn{2}{|c|}{$\mathrm{d}(\mathrm{mm})$} & $32.87 \mathrm{a}$ & $31.17 \mathrm{~b}$ & $32.45 \mathrm{a}$ & $30.17 \mathrm{c}$ & $32.44 \mathrm{a}$ & $30.86 \mathrm{bc}$ \\
\hline \multicolumn{2}{|c|}{$\mathrm{h}(\mathrm{mm})$} & $8.65 b c$ & $9.17 \mathrm{ab}$ & $8.43 b$ & $8.65 b c$ & $8.19 \mathrm{~b}$ & $9.58 \mathrm{a}$ \\
\hline \multicolumn{2}{|c|}{$\mathrm{SR}(-)$} & $3.83 \mathrm{a}$ & $3.40 \mathrm{~b}$ & $3.85 \mathrm{a}$ & $3.49 \mathrm{~b}$ & $3.96 \mathrm{a}$ & $3.23 \mathrm{~b}$ \\
\hline \multicolumn{2}{|c|}{ Hardness (g) } & $5347 \mathrm{ab}$ & $3192 \mathrm{e}$ & $4392 \mathrm{~cd}$ & $4903 \mathrm{bc}$ & 3768de & $5854 \mathrm{a}$ \\
\hline \multirow{2}{*}{$\mathrm{L}^{*}$} & upper & $77.42 \mathrm{a}$ & $64.68 \mathrm{c}$ & $64.49 \mathrm{c}$ & $58.91 d$ & $70.73 b$ & $56.62 \mathrm{e}$ \\
\hline & lower & $72.30 \mathrm{a}$ & $62.90 \mathrm{~b}$ & $58.43 \mathrm{c}$ & $55.65 \mathrm{~d}$ & $63.82 \mathrm{~b}$ & $53.03 \mathrm{e}$ \\
\hline \multirow{2}{*}{$a^{*}$} & upper & $-1.03 e$ & $4.97 \mathrm{c}$ & $5.73 b$ & $5.57 \mathrm{~b}$ & $2.90 \mathrm{~d}$ & $7.32 \mathrm{a}$ \\
\hline & lower & $3.07 \mathrm{c}$ & $5.90 \mathrm{~b}$ & $10.15 \mathrm{a}$ & $9.86 a$ & $7.12 \mathrm{~b}$ & $9.31 \mathrm{a}$ \\
\hline \multirow{2}{*}{$b^{*}$} & upper & $31.32 b$ & $26.33 d$ & $30.36 c$ & $27.07 \mathrm{~d}$ & $32.85 a$ & $24.40 \mathrm{e}$ \\
\hline & lower & $34.60 \mathrm{~b}$ & $28.46 \mathrm{e}$ & $33.06 \mathrm{c}$ & $30.69 \mathrm{~d}$ & $36.37 \mathrm{a}$ & $26.65 f$ \\
\hline
\end{tabular}

Data are presented as means of all replicates. Values in the rows followed by different lowercase letters are significantly different $(p<0.05)$.

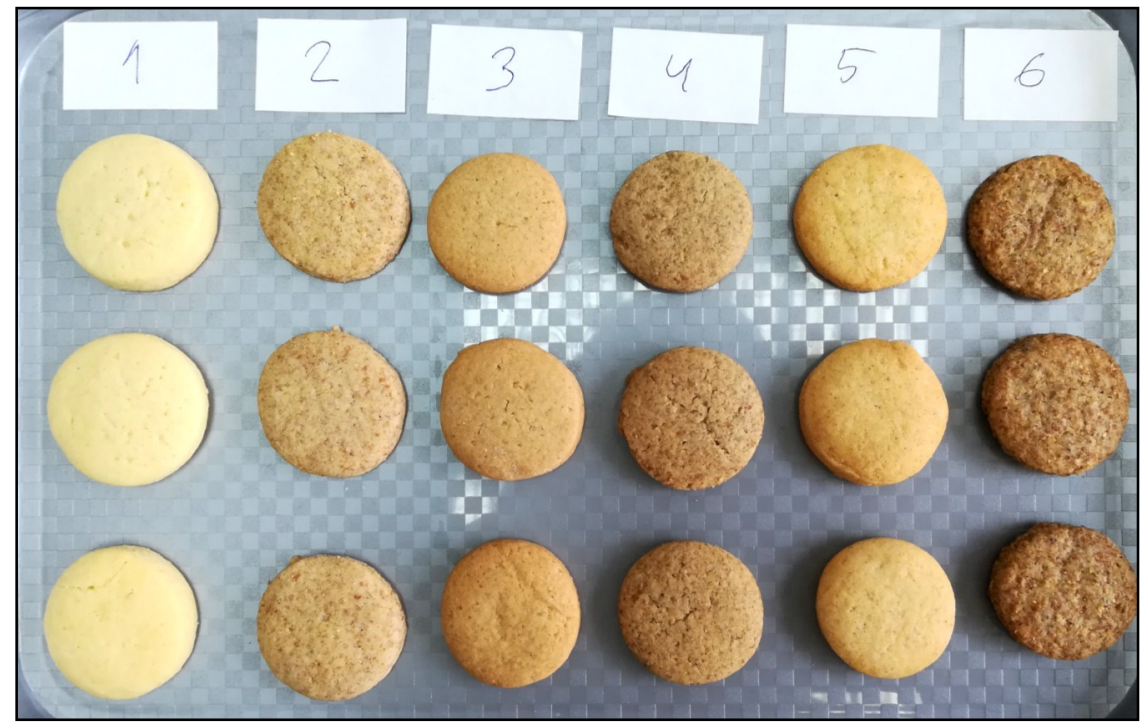

Figure 1. Cookies prepared from refined wheat flour (sample 1), wholegrain wheat flour (sample 2), refined rye flour (sample 3), wholegrain rye flour (sample 4), refined triticale flour (sample 5) and wholegrain triticale flour (sample 6) 
Table 4. Sensory scores of cookies

\begin{tabular}{|c|c|c|c|c|c|c|}
\hline Quality parameter & $\begin{array}{c}\text { Refined } \\
\text { wheat flour }\end{array}$ & $\begin{array}{l}\text { Wholegrain } \\
\text { wheat flour }\end{array}$ & $\begin{array}{c}\text { Refined rye } \\
\text { flour }\end{array}$ & $\begin{array}{c}\text { Wholegrain } \\
\text { rye flour }\end{array}$ & $\begin{array}{c}\text { Refined } \\
\text { triticale flour }\end{array}$ & $\begin{array}{l}\text { Wholegrain } \\
\text { triticale flour }\end{array}$ \\
\hline Appearance & 3.6 & 4.2 & 3.9 & 3.8 & 4.5 & 3.3 \\
\hline Structure and fracturability & 5.0 & 5.0 & 5.0 & 4.0 & 4.0 & 3.4 \\
\hline Chewiness & 5.0 & 4.2 & 4.9 & 4.1 & 5.0 & 3.4 \\
\hline Odor & 4.5 & 4.2 & 3.9 & 4.0 & 4.4 & 4.8 \\
\hline Taste and flavor & 3.8 & 3.7 & 4.7 & 3.8 & 5.0 & 4.2 \\
\hline Total score & 17.4 & 16.9 & 18.1 & 15.7 & 18.4 & 15.2 \\
\hline Quality class & Very good & Very good & Very good & Good & Very good & Good \\
\hline
\end{tabular}

Data are presented as means of all replicates.

Regarding the color properties, significantly darker color (lower $L^{*}$ values) of cookies prepared from refined triticale flour in comparison to cookies prepared from refined wheat flour was previously observed by Dennett \& Trethowan (2013). In their study, darker color was related to higher ash content of refined triticale flour, and it was concluded that this color can be desirable in cookie production, especially in products intended for health-conscious individuals. In our study, all flours with higher ash content (wholegrain flours) had significantly lower $\mathrm{L}^{*}$ values than the corresponding refined flour, supporting this conclusion. Additionally, color of cookie surface is developed by Maillard and caramelization reactions and therefore is closely related to the free amino acid and sugar content (Oliete et al. 2010). More pronounced red tone (higher $a^{*}$ values) of rye and triticale cookies observed in our study is probably the consequence of higher content of free amino acids in these flours, because sugar is added to all cookies in the same amount.

According to the scoring method, the sensory quality of cookies was assessed as good and very good (Table 4). Wholegrain rye and triticale flour cookies received lower scores because of their deformed shape, cracked surface, crumbliness and rough structure perceived during consumption. Generally, structure of non-wheat cookies was crumblier presumably due to higher dietary fiber content. However, these samples received higher scores for taste and flavor, which are richer due to the higher amount of amino acids reacting with sugars at baking temperature (Gavrilović, 2000). Cookies prepared from refined triticale flour were assessed with the highest score because of excellent appearance, chewiness, taste and flavor.

\section{Conclusions}

The obtained values of grain quality parameters indicate that triticale cultivar Odisej could be used in confectionary industry for the production of cookies using similar formulation and technological process. Spread ratio of cookies manufactured from refined triticale flour did not differ significantly from refined wheat flour cookies. Its instrumentally determined hardness and sensory scores for structure and chewiness were in the range obtained for wheat flour cookies. Appearance of refined triticale flour cookies was assessed as very good to excellent and its total score was the highest among all samples, indicating that it can be used in cookies production. However, cookies prepared from wholegrain triticale flour had the lowest spread ratio and the lowest score for appearance due to uneven shape and deep cracks. Its texture was assessed as too hard and crumbly, giving it the lowest total score. These sensory properties were caused by the presence of larger bran particles obtained by milling technique adapted for the production of refined flour. Therefore, the use of milling technique adequate for the production of wholegrain flour would improve the quality of cookies. Further research is necessary to determine whether refined triticale flour could be successfully used in the production of other baked confectionary products.

\section{References}

AACC (2000a). Baking quality of cookie flour - Micro Wire-Cut Formulation. Approved Methods of the American Association of Cereal Chemists (10 th ed.) St. Paul, MN, USA, Method 10-54.01.

AACC (2000b). Crude Protein - Improved Kjeldabl Method. Approved Methods of the American Association of Cereal Chemists $\left(10^{\text {th }}\right.$ ed.) St. Paul, MN, USA, Method 46-10.

CEN (2008). Cereals and cereal products - Common wheat (Triticum aestivum L.) - Determination of alveograph properties of dough at adapted hydration from commercial or test flours and test milling methodology. Brussels, Belgium: European Committee for Standardization CEN/TS 15731:2008 (E).

Dennett, A. L., \& Trethowan, R. M. (2013). Milling efficiency of triticale grain for commercial flour production. Journal of Cereal Science, 57 (3), 527-530.

Dennett, A. L., Wilkes, M. A., \& Trethowan, R. M. (2013). Characteristics of modern triticale quality: The relationship between carbohydrate properties, $\alpha$-amylase activity, and falling number. Cereal Chemistry, 90, 594-600.

Gavrilović, M. (2000). Tebnologija konditorskih proizvoda (Technology of Confectionary Products). Novi Sad, Serbia: Faculty of Technology.

Grabovets, A. I., Dremucheva, G. F., \& Karchevskaya, O. E. (2013). Breeding of triticale for baking purposes. Russian Agricultural Sciences, 39 (3), 197-202.

Hadnađev, T. R. D., Torbica, A. M., \& Hadnađev, M. S. (2013). Influence of buckwheat flour and carboxymethyl cellulose on rheological behaviour and baking performance of gluten-free cookie dough. Food and Bioprocess Technology, 6(7), 1770-1781. 
Hammer, K., Filatenko, A. A., \& Pistrick, K. (2011). Taxonomic remarks on Triticum L. and $\times$ Triticosecale Wittm. Genetic Resources and Crop Evolution, 58 (1), 3-10.

http: / / www.sorte.minpolj.gov.rs/sites/default/files / rsprilogom_3.pdf, Retrieval date: 22.11.2019.

ICC (1984). Working method for the determination of wet gluten in wheat flour. Vienna, Austria: International Association for Cerea Chemistry Standard Method 106/2.

ICC (1994). Determination of wet gluten quantity and quality (Gluten Index ac. to Perten) of whole wheat meal and wheat flour (Triticum aestivum). Vienna, Austria: International Association for Cereal Chemistry Standard Method 155.

ISO (2009). Wheat, rye and their flours, durum wheat and durum wheat semolina - Determination of the falling number according to Hagberg-Perten. Geneva, Switzerland: International Organization for Standardization ISO 3093:2009(E).

ISO (2010). Cereals and pulses - Determination of the mass of 1 000 grains. Geneva, Switzerland: International Organization for Standardization ISO 520:2010.

ISO (2010). Sensory analysis - General guidance for the design of test rooms. Geneva, Switzerland: International Organization for Standardization ISO 8589:2010+A1:2014.

ISO (2009). Cereals and cereal products - Determination of moisture content — Reference method. Geneva, Switzerland: International Organization for Standardization ISO 712:2009.

ISO (2019). Cereals — Determination of bulk density, called mass per hectolitre - Part 3: Routine method. Geneva, Switzerland: International Organization for Standardization ISO 7971-3:2019.

Leon, A. E., Rubiolo, A., \& Anon, M. C. (1996). Use of triticale flours in cookies: Quality factors. Cereal Chemistry, 73 (6), 779-784

Malešević, M., Aćin, V., Jaćimović, G., Hristov, N., Bogdanović, D. Marinković, B, \& Latković, D. (2010). Sowing dates and densities of winter wheat in long-term trials. In Proceedings of the $22 \mathrm{nd}$ International Symposium Food Safety Production, 19-25 June 2011, Trebinje, Bosnia and Herzegovina, ed. By Krajinović M. University of Novi Sad, Faculty of Agriculture, Novi Sad, 314 317.
Maširević, S., Radujkov, D., Jevtić, R., \& Stajković, N. (2013). Occurrence of Fusarium Head Blight on some wheat varieties on different plant population and nitrogen fertilisation during 2011 in Serbia. Research Journal of Agricultural Science, 45(1).

McGoverin, C. M., Snyders, F., Muller, N., Botes, W., Fox, G., \& Manley, M. (2011). A review of triticale uses and the effect of growth environment on grain quality. Journal of the Science of Food and Agriculture, 91 (7), 1155-1165.

Oliete, B., Pérez, G. T., Gómez, M., Ribotta, P. D., Moiraghi, M., \& León, A. E. (2010). Use of wheat, triticale and rye flours in layer cake production. International Journal of Food Science \& Technology, 45 (4), 697-706.

Pajin B. (2009). Praktikum iz tehnologije konditorskih proizvoda (Practicum in Technology of Confectionary Products). Novi Sad, Serbia: Faculty of Technology.

Pérez, G. T., León, A. E., Ribotta, P. D., Aguirre, A., Rubiolo, O. J., \& Añón, M. C. (2003). Use of triticale flours in cracker-making. European Food Research and Technology, 217 (2), 134-137.

Perten, H. (1964). Application of the falling number method for evaluating alpha-amylase activity. Cereal Chemistry, 41(3), 127140.

Roccia, P., Moiraghi, M., Ribotta, P. D., Perez, G. T., Rubiolo, O. J., \& Leon, A. E. (2006). Use of solvent retention capacity profile to predict the quality of triticale flours. Cereal Chemistry, 83(3), 243-249.

Stallknecht, G. F., Gilbertson, K. M., \& Ranney, J. E. (1996). Alternative wheat cereals as food grains: Einkorn, emmer, spelt, kamut, and triticale. Progress in New Crops, 156-170.

Torbica, A., Hadnađev, M., \& Hadnađev, T. D. (2012). Rice and buckwheat flour characterisation and its relation to cookie quality. Food Research International, 48 (1), 277-283.

Wu, Y. V., Stringfellow, A. C., Anderson, R. A., Sexson, K. R., \& Wall, J. S. (1978). Triticale for food uses. Journal of Agricultural and Food Chemistry, 26 (5), 1039-1048.

Zhu, F. (2018). Triticale: Nutritional composition and food uses. Food Chemistry, 241, 468-479.

\title{
Potencijalna primena sorte tritikalea „Odisej" u proizvodnji čajnog peciva
}

\author{
Miona Belović · Aleksandra Torbica · Dubravka Škrobot · Jelena Tomić · \\ Ivana Čabarkapa · Dragan Živančev · Slaviša Štatkić · Vladimir Aćin · \\ Kristína Kukurová · Zuzana Ciesarová
}

\begin{abstract}
Sažetak: Tritikale, hibridna žitarica dobijena ukrštanjem pšenice i raži, ima određene prednosti u odnosu na pšenicu, kao što su veća otpornost prema uslovima sredine i veći sadržaj prehrambenih vlakana. Primena brašna tritikalea u prehrambenoj industriji ograničena je lošim reološkim svojstvima testa i slabim glutenom. U ovoj studiji istražena je potencijalna primena heksaploidne sorte tritikalea „Odisej“ u proizvodnji čajnog peciva. Pored toga, utvrđene su vrednosti osnovnih pokazatelja kvaliteta zrna (hektolitarska masa, masa 1000 zrna, veličina zrna, sadržaj proteina i vlažnog glutena, gluten indeks i broj padanja) za sortu „Odisej“. Čajna peciva su pripremljena od belog i integralnog brašna tritikalea, a njihova fizička svojstva (dimenzije, boja, tvrdoća) i senzorska svojstva upoređena su sa čajnim pecivima pripremljenim od belog $\mathrm{i}$ integralnog pšeničnog $\mathrm{i}$ raženog brašna. Čajna peciva proizvedena od belog brašna tritikalea imala su vrednost odnosa širenja (prečnik/visina) sličnu vrednosti dobijenoj za čajno pecivo od belog pšeničnog brašna. Zbirna ocena senzorskog kvaliteta čajnog peciva proizvedenog od belog brašna tritikalea bila je najveća među svim uzorcima, što ukazuje da se belo brašno tritikalea može uspešno koristiti u proizvodnji čajnog peciva. Kvalitet čajnog peciva od integralnog brašna tritikalea mogao bi da se poboljša primenom tehnike mlevenja koja je adekvatna za proizvodnju integralnog brašna.
\end{abstract}

Ključne reči: čajno pecivo, pšenica, sorte, tritikale, zrno 